Ivan Sokolov", Ph.D.

ПРЕГЛЕДНИ НАУЧНИ РАД

Associate Professor,

doi:10.5937/zrpfni1878255S

European Higher School of Economics and Management

Plovdiv, Bulgaria

UDK: 336.02:352

Рад примљен: 30.03 .2018$.

Рад прихваћен: 18.04.2018.

\title{
LOCAL FINANCIAL INVESTMENT POLICY
}

\begin{abstract}
For decades, while reforming their administrative system, EU countries have put their emphasis on the development and strengthening of local self-government. In the framework of the large-scale decentralization policy, physical and institutional boundaries of local development are established and the local self-government units are vested with full statutory powers and responsibilities deemed specifically theirs. The constitutions of the countries in Europe are the main source of law regulating the local self-government and governance.
\end{abstract}

Keywords: local self-government, municipal investment policy, public and private property, investment risk.

\section{Introduction}

Municipal investment policy is defined as a system of elements (funds) and mechanisms for their implementation that ensure the achievement of certain investment objectives and tasks in the development of the municipality. It is related to an efficient investment expenditure in order to increase the technical, technological and organizational level of the municipal economy, ensuring high quality production at low cost, optimal assortment and strong market positions. It is built on the basis of objective analysis and assessment of the municipal economy as a whole, the state of the social and technical infrastructure, as well as the ecological status of the municipality. It is aimed at creating conditions for placement of national and international investments.

\section{Financing of local public investment projects: Sources and institutionalization}

The financing of investment programs and projects in Bulgaria is done in two ways: decentralized and centralized.

*i.sokolof@abv.bg 
At this stage, the subject of decentralized financing are currently the municipalities. District administrations have very limited financial powers, restricted only to the management of the financial resources needed for their own building and operation. Municipalities have better-developed administrative structures with more experience in managing and implementing investment programs and projects.

The collective management scheme implemented through the will and decisions of the municipal councils sometimes hinders the purposeful implementation of the complex and wide-ranging programs for development of the municipalities as well as for the realization of projects of inter-municipal and regional interest.

Centralized financing of investment programs and projects is carried out through the central executive authorities: ministries, agencies and other structures with national competences. Primarily, projects of socio-economic importance exceeding the local interests, such as projects whose beneficiaries are several municipalities or districts, are financed. A significant part of the regional projects are financed by:

- Ministry of Regional Development and Public Works (in the field of road infrastructure, drinking water supply, cross-border cooperation, etc.);

- Ministry of Agriculture (in the field of irrigation and water engineering);

- Ministry of Environment and Water (in the field of wastewater treatment and waste management);

- Ministry of Labour and Social Policy (in the field of social welfare).

In most cases, investment programs and projects are financed on a mixed basis, from various internal or external sources.

In compliance with the provisions of the Municipal Debt Act, the Ministry of Finance maintains a Central Register of Municipal Debt. The register is a guarantee of publicity of information, and it is in compliance with the transparency requirements for the disposal of public funds.

\subsection{Internal sources and forms of their provision}

\subsubsection{State budget}

The state budget funds are channeled for the implementation of programs and projects through central executive authorities and through municipalities. The state budget finances municipal projects and programs through targeted subsidies for capital expenditure, determined annually in the State Budget Act. Target subsidies are provided under certain conditions prescribed in the State Budget 
Act. These are first and foremost the requirements for preferential provision of sites in certain sectors (e.g. drinking water supply, health and welfare, education and environmental protection) as well as sites with the highest degree of construction completion (with the closest term of commissioning). In addition to targeted subsidies, the Bulgarian financial legislation regulates the possibility of granting budget subsidies, which represent a certain variety of subsidies and are granted under certain conditions. For the time being, this form of budget support is not applied in practice, although it is particularly suited to a targeted government impact on the implementation of certain programs. A specific way of program financing from the budget is the allocation of funds for the construction, reconstruction and overhaul of sites from the fourth-class road network.

\subsubsection{Own funds of the municipalities}

According to their origin, these funds are of two types: the municipality's own budget and own extra-budgetary funds. They are allocated and directed for the implementation of programs and projects by decision of the local self-government bodies - the municipal councils.

The main extra-budgetary source are the proceeds from the privatization of municipal sites. Obviously, over time, this source will lose its significance as the base of this revenue will increasingly narrow. In this situation, the importance of own budget resources for the realization of the municipal investment policy will increase.

The possibilities for financing investment projects with own funds from the municipal budgets do not depend only on the efforts of the local authorities. They are a function of the state's policy on strengthening the economic foundations of local self-government by providing more and more stable own revenues in municipal budgets, providing significant amounts of regular revenue.

\subsubsection{Centralized public extra-budgetary funds}

Funding from these sources is usually done on an individual basis, on a competitive basis, in compliance with a set of requirements, criteria and indicators.

\subsubsection{Private financial resources}

Private capital participation should be sought in areas with economic returns (e.g. in the development of: tourism, commercial activities, entertainment, leisure and sports activities, and expanding health and education services against pay, etc.). In many countries, reliance is being placed on mixed funding, including both 
private and public funds, for the effective implementation of certain development projects. Appropriate instruments in this regard are public-private partnerships.

\subsubsection{External sources and forms of their provision}

Bulgaria's accession to United Europe marks the start of a new stage in the implementation of local investment policy and in the financing of municipal programs and projects. As a member of the European Union, Bulgaria has the opportunity to make use of the Structural Funds and the other financial instruments of the Union.

The municipalities are the main beneficiaries in the absorption of the Eurofunds under two operational programs (OPs): OP "Regional Development" and OP "Environment". Projects are financed that relate to:

- $\quad$ investments in road infrastructure;

- $\quad$ investments in water supply and sewerage systems;

- $\quad$ investments in environmental infrastructure, including waste treatment infrastructure;

- $\quad$ investment in tourism infrastructure.

The municipalities have the opportunity to participate in a limited number of operations under OP "Human Resources Management" (mainly with social projects targeting vulnerable groups) and OP "Administrative Capacity" (mainly as target groups for capacity building rather than direct beneficiaries).

How far these opportunities will be used as a positive development impetus depends to a large extent on the initiative and adaptability of the municipalities to the new conditions.

\subsection{Quantitative measures and comparability with other EU Member States}

Share of local investment in total public investment (as of May 2015, Eurostat)

The indicator gives an idea of the distribution of investment between levels of government in the public sphere. The share of the capital expenditure of the municipalities in Bulgaria compared to the total amount of the public investments increased sharply during the period under review, reaching 64\% in 2014. This puts it in the first place, ahead of all the unitary states in the EU, including those with long-standing traditions such as France, Italy, the Netherlands. All of this is happening against the backdrop of the overall decline in this indicator in other European countries. Countries above the EU-28 average are the Czech 
Republic, Poland, Romania and Slovenia, and in the last places are the usual countries without Portugal, which (with a $45 \%$ share) is immediately above the EU average of nearly $45 \%$.

\subsection{Institutional organization}

The successful formation and implementation of the municipal investment policy depends on:

- the availability of administrative and managerial personnel to plan, organize, account and control the implementation of municipal investment programs;

- the availability of organizational and technical conditions for the development and evaluation of effective projects;

- the existence of organizational and management experience of administrative staff to prepare the overall investment-related procedure;

- the availability of practical knowledge in the implementation of the existing legislation, which can lead the investment initiative to a concrete realization.

In this regard, it is necessary to know the different stages of the investment policy related to the established procedures for:

- exploration and design under the Spatial Planning Act;

- environmental impact assessment according to the Environmental Protection Act;

- the cost-benefit assessment requiring specialized knowledge of the profitability assessment methodologies;

- the rate of return of the investment; annual operating costs; social cost of the investment, etc.;

- programming and planning of investment expenditures from state and municipal budgets and extrabudgetary funds according to the Law for the Structure of the State Budget and the Municipal Budgets Act;

- subsidizing programs and projects from: the European Union Structural Funds (via the National Operational Programs); national plans and programs in the fields of economic development, social and regional policy, agriculture and rural regions, etc.

- preparation of tender procedures (knowledge of international practice and rules);

- award of public procurement under the Public Procurement Act; 
- individualization and disposition of immovable property in accordance with the State Ownership Act, the Municipal Property Act, the Concessions Act, the Specialized Laws on Roads, Waters, Energy and Energy Resources, Telecommunications, Civil Aviation, etc .;

- change of destination of agricultural land and land from the forest fund;

- observance of the rules on building supervision and state acceptance of buildings and facilities, as well as requirements for the delivery of machinery, equipment, etc.

Municipalities should institutionalize their investment policy in order to create a working model for identifying investment needs at municipal and urban level, for planning capital expenditure in the long-term perspective and for assessment of the available local and potential external financial resources.

The municipal investment policy can be organized and coordinated by a branch deputy mayor or the municipality's chief financial officer responsible for:

- conducting the entire investment process and coordinating the participants in it;

- coordinating the budget and investment programs of municipal companies (projects partly or wholly financed by the municipal budget);

- exercising control over the work of the municipal investment service;

- submitting a preliminary draft (project) of the capital investment program and the capital budget for the budget year concerned;

- cooperation with civil society structures;

- monitoring the policy and drafting recommendations for its improvement.

An important moment in the implementation of the municipal investment policy is the administration of the capital budgeting process. It may be carried out by a steering group established by a decision of the municipal council. It is recommended that the group includes the mayor of the municipality and the chairman of the municipal council, representatives of the municipal administration, the municipal council, representatives of the civil society, and business structures.

The main functions of the steering group are related to:

- consideration of the submitted proposals for investment projects;

- analysing the organizational, technical and financial capabilities for the implementation of a project;

- setting the priorities for evaluating the investment projects; 
- $\quad$ assessment of municipal investment projects in accordance with accepted methodology;

- approving projects for preparatory stage and proposing projects for inclusion in the investment plan;

- drafting a proposal for the one-year capital budget (the investment program for the forthcoming year) and its presentation to the municipal council;

- coordination of possible sizes and sources of financing with the financial unit that prepares the financial forecast;

- $\quad$ annually updating the CIP (Competitiveness and Innovation Programs).

An important task of the steering group is to organize and control the preparation of a complete inventory of all sites - public and private municipal property. The document should cover public buildings and facilities, including roads and infrastructure to provide utilities (e.g. plumbing and sewerage systems, treatment plants, landfills).

The inventory identifies the needs for overhaul, reconstruction or replacement of individual infrastructure sites and facilities, as well as the need to build new ones. The document should contain information about:

- the life cycle of the existing sites and facilities, including the year of their construction, acquisition and entry into service;

- $\quad$ the cost of acquisition;

- the degree of coverage on the territory of the municipality with the relevant service (e.g. the water supply level with drinking water) or the degree of satisfaction with a particular public service as a percentage of the need;

- the capacity of the site (the facility) in the relevant unit of measurement;

- $\quad$ the physical state of the existing sites and facilities (good, medium, poor) and the date of the last improvement;

- the rate of use (low, medium, high) and the planned year/date for new investment expenditure;

- $\quad$ the indicative value of a possible new investment expenditure.

Another task of the steering group is to identify and analyse: the progress made on capital projects undergoing technical implementation; the amount of funds that will be needed for absorption in the coming years; the state of unfinished projects. The results of this analysis should be presented in a report to the draft 
of the capital budget and the capital investment program submitted to the municipal council for consideration and approval.

Each municipality has a structural unit that administers the investment process. Typically, this is a capital investment department that has the following functions:

- collection and verification of application forms (project proposals);

- $\quad$ establishing the compliance of the investment strategy projects and the long-term development plan of the municipality;

- identifying the links and relationships between new projects and those under implementation; the capital investment program and the investment projects of the municipal enterprises;

- cooperating with: the relevant departments or units (internal or external to the municipality) involved in the implementation of projects and the monitoring of the investment activity; external investors, in connection with some necessary adjustments and agreements;

- $\quad$ assisting the Steering Group to provide the necessary data and material.

Municipal investment projects may be initiated and submitted by:

- $\quad$ the mayor or his deputies;

- the municipal council (chairman, deputy chairpersons, municipal councillors, permanent or temporary committees);

- $\quad$ representatives of schools, sports units, contractors of municipal services;

- municipal companies that have investment intentions and which are financed or co-financed by the municipal budget;

- $\quad$ inhabitants of the municipality (usually represented by civilian groups);

- local non-governmental organizations, public institutions and other local community representatives;

- representatives of the local business.

The institutional organization of each particular investment project is based on the document "Strategy for the management of human resources in the project".

It is obligatory for each investment project to draw up a list of the participants in the project, the possible participants being the following:

- $\quad$ first level spending unit (FLSU);

- $\quad$ second level spending unit (SLSU); 
- municipal council, mayor of the municipality;

- investor;

- project manager (obligatory for projects worth more than BGN 1000 000);

- management team (obligatory for projects worth more than BGN 10000 000);

- main contractor and subcontractors;

- suppliers;

- designers;

- representatives of state institutions - ministries, agencies etc.

- owners of the immovable property on which the site will be built;

- initiators;

- users of the project product;

- public groups of the population;

- competitors;

- other interested persons (related to the direct benefits of the project).

The functions of the individual participants may overlap. In such a case, they must be described in an explanatory note to the document.

The organizational structure represents the organizational relationship between the different project participants. The main factors to be taken into account when developing the organizational structure are the specialized division of labour and the volume of work performed.

The job description is developed only for projects worth over BGN 10000000 . The purpose of the job description is to clearly distinguish the positions, responsibilities, obligations and competencies of the individual project participants. The content of the job description is standard.

For projects worth over BGN 1000 000, it is obligatory to determine the working hours of the individual project participants. This is necessary in order to achieve a coordinated implementation of the activities over time as well as to calculate the duration of the work.

The matrix of distribution of responsibilities between project participants is presented in the following table. 
Table 1. Matrix of distribution of responsibilities between participants in an investment project

Participants in the project
Participant 1
Participant 2
Participant 3
Participant N

Work 1
X
X
X

Works in the project

\begin{tabular}{|c|c|c|}
\hline Work 2 & & Work N \\
\hline & & \\
$\mathrm{X}$ & $\mathrm{X}$ & $\mathrm{X}$ \\
& $\mathrm{X}$ & $\mathrm{X}$ \\
$\mathrm{X}$ & & \\
$\mathrm{X}$ & $\mathrm{X}$ & \\
\hline
\end{tabular}

The participants in the project are shown in the vertical direction. The horizontal direction indicates the main works to be performed. Against each participant it is noted which of the main activities he/she is responsible for.

\section{Selection, evaluation and impact of investment projects financed by public funds}

Exemplary criteria for the evaluation of strategic investment projects are presented in the following table

Table 2. Exemplary criteria for the evaluation of strategic investment projects

\begin{tabular}{|l|l|l|l|}
\hline Evaluation criteria & Definition / explanation & $\begin{array}{l}\text { Maximum } \\
\text { points }\end{array}$ & $\begin{array}{l}\text { Percentage of } \\
\text { weight (\%) }\end{array}$ \\
\hline 1 & 2 & 3 & 4 \\
\hline $\begin{array}{l}\text { Priority in the } \\
\text { strategy/plan for } \\
\text { development of the } \\
\text { municipality }\end{array}$ & $\begin{array}{l}\text { Ranking of the project among the } \\
\text { priorities in the municipal strategy } \\
\text { documents: from 10 for the highest } \\
\text { rated project to 0 for a project ranked } \\
\text { at a lower priority level }\end{array}$ & $0-10$ & up to 100\% \\
\hline Safety & $\begin{array}{l}\text { The extent to which the project } \\
\text { eliminates, prevents or reduces } \\
\text { immediate security dangers }\end{array}$ & $0-10$ & up to 100\% \\
\hline Delegated obligations & $\begin{array}{l}\text { The extent to which the project has } \\
\text { been delegated by an institution such } \\
\text { as MoF or MoEW, etc. }\end{array}$ & $0-10$ & up to 100\% \\
\hline Economic impact & $\begin{array}{l}\text { The extent to which the project } \\
\text { strengthens economic development } \\
\text { in the municipality by protecting the } \\
\text { environment or directly or indirectly } \\
\text { contributing to the tax base }\end{array}$ & $0-10$ & up to 100\% \\
\hline
\end{tabular}




\begin{tabular}{|c|c|c|c|}
\hline Efficiency & $\begin{array}{l}\text { The extent of capital expenditure } \\
\text { efficiency }\end{array}$ & $0-10$ & up to $100 \%$ \\
\hline $\begin{array}{l}\text { Degree of readiness of } \\
\text { the project }\end{array}$ & $\begin{array}{l}\text { Existence of a preliminary study and } \\
\text { technical and economic justification of } \\
\text { the project }\end{array}$ & $0-10$ & up to $100 \%$ \\
\hline $\begin{array}{l}\text { Maintaining the } \\
\text { current level of } \\
\text { services }\end{array}$ & $\begin{array}{l}\text { The extent to which the project is } \\
\text { needed to enable the municipality } \\
\text { to continue to provide one or more } \\
\text { services at the current level }\end{array}$ & $0-10$ & up to $100 \%$ \\
\hline Improving the service & $\begin{array}{l}\text { The extent to which the project } \\
\text { contributes to improving the quality of } \\
\text { existing services }\end{array}$ & $0-10$ & up to $100 \%$ \\
\hline Adding services & $\begin{array}{l}\text { The extent to which the project } \\
\text { increases the quantity of existing } \\
\text { services }\end{array}$ & $0-10$ & up to $100 \%$ \\
\hline $\begin{array}{l}\text { Impact on the } \\
\text { operating budget }\end{array}$ & $\begin{array}{l}\text { Projects that reduce future operating } \\
\text { expenditure receive a positive score } \\
\text { from } 0 \text { to } 10 \text {. Projects that have no } \\
\text { impact on operating expenditure } \\
\text { are rated } 0 . \text { Projects that increase } \\
\text { operating income receive a rating } \\
\text { between } 0 \text { and } 10 .\end{array}$ & $0-10$ & up to $100 \%$ \\
\hline Public support & $\begin{array}{l}\text { The extent to which the project has } \\
\text { broad and / or strong support from } \\
\text { the public and is consistent with the } \\
\text { strategic or other long-term plans of } \\
\text { the municipality }\end{array}$ & $0-10$ & up to $100 \%$ \\
\hline Reliability of financing & $\begin{array}{l}\text { The extent to which project financing } \\
\text { sources are involved (including co- } \\
\text { financing, public-private partnership) }\end{array}$ & $0-10$ & up to $100 \%$ \\
\hline Maximum percentage & & & up to $100 \%$ \\
\hline
\end{tabular}

Each member of the Steering Group gives a quantitative assessment of the projects for each criterion on a scale adopted according to a specific methodology. The resulting individual assessment is final and not subject to change until the next evaluation procedure. Once they have been prepared, the individual assessments of all project criteria are provided to the Chairman of the Steering Group.

For each evaluation criterion a scale of 0-5-10 points (0 - minimum score, 10 maximum) is used. The rating scale for each criterion is divided at the following intervals:

- rating 0: no impact or negative impact on the relevant criterion;

- rating to 2: low impact on the relevant criterion; 
- rating to 5: good impact;

- rating to 7: strong impact;

- rating 10: clearly expressed high impact.

After the evaluations have been received on all criteria and on all projects, the projects should be ranked in descending order.

The Chairman of the Steering Group informs the mayor in writing of the results of the project evaluation. Upon completion of the evaluation process, each project receives a final digital evaluation. This evaluation is a criterion for the decision to include the projects in the annual investment program of the municipality.

For smaller municipal software projects, it is advisable to select no more than 4-7 criteria. It is also appropriate to adopt a simpler evaluation scale (rating from 0 to 6$)$.

\section{Conclusion}

Although in 2007 the municipalities in the country were given the power to determine local taxes within specific limits, according to the Local Taxes and Fees Act, and subsequently these limits were extended, local finance problems were not solved. The revenues of the municipalities did not increase substantially and their structure was not changed.

Deficits increased significantly over a period of time, reaching more than $15 \%$ of municipal own revenues - totaling over BGN 500 million in 2010. The increased deficits and the decreased revenues led to an increase in the municipal debt. At the end of 2011, this debt amounted to BGN 950 million, with the foreign debt, albeit slightly exceeding the domestic debt. The subsequent reduction of the deficit was due to its funding, mostly domestic.

At the beginning of 2016 the total arrears of the municipalities were about BGN 160 million.

The financial local independence is not available due to the fact that only about $10 \%$ of the budget revenues are from local taxes. Rare are the cases of higher own revenues, mainly due to fees.

Local budgets are being fed mainly by transfers from the central budget, from non-tax revenues/municipal property and local taxes/ and tax revenues.

A system where the direct and indirect taxes enter in the State budget as the main source of revenue for the central budget, followed by the drawing up of other budgets and the distribution of funds, is not a basis for financial local 
independence. In the case of a major failure in the revenues of municipalities or insurance institutions, the central budget provides insufficient funds, and the deprivation of such funds implies even less maneuverability. This suggests that the timing of remise of taxes to the municipalities is postponed.

There have been no significant changes in local taxes and fees in recent years. The most frequent are the changes to the patent tax for retail trade, and the most common is the fee for municipal waste for non-residential property of legal entities. For example, garbage fee has been reduced more times (58) than it has been increased (48) for the entire period 2013-2015 (IME). These changes did not lead to an increase in revenue.

Relying mostly on subsidies and transfers, many municipalities are in financial difficulties, leading to the attachment of their accounts and lack of the ability to make payments. According to the data of the National Association of the Municipalities of the Republic of Bulgaria, about 60-70 municipalities are facing serious financial difficulties as of January 2016. In practice, every fourth municipality is threatened.

With regard to investments in municipalities, the following conclusions ensue:

- First, the level of local taxes and fees is largely a consequence of the availability or lack of investment and working business, and in the largest economic centres the levels of local taxes and fees remain relatively high, while they are relatively low in the less developed areas.

- Second, neither high local taxes and fees repulse investors to start a business and the population to settle in areas with a relatively high tax burden, nor low local taxes and fees manage to attract entrepreneurs and migrants to less developed areas.

The real problems of local finances will not be resolved by changing one law, but the bill on amending the Public Finance Act is a step forward in this direction. The main changes are as follows:

- municipalities will be able to open financial recovery procedures and take measures to achieve financial sustainability and stability of local finances.

- municipalities will be able to raise taxes and local fees.

- temporary interest-free loans will be granted for the purpose of implementing the municipal financial recovery plan with a fixed reimbursement period.

The development of the Ministry of Finance's IT infrastructure and the significant results of its implementation at local level is also a step forward. More 
than 200 municipalities use the software of the Ministry of Finance for processing local taxes and fees. This infrastructure also allows full exchange of data between municipalities and MoF.

With a free personal identification code (PIC), which anyone can obtain from the tax administration at their place of residence, citizens will be able to check their tax account with the National Revenue Agency (NRA) and their local tax and duty obligations without needing digital signature. The service started as pilot in Sofia Municipality and Veliko Tarnovo municipality and gradually covered other municipalities using the MoF system.

Expectations for local finance stability are related to the implementation of tighter financial policies by municipalities, reduction of transfers from the central budget, local authority powers in terms of tax and fee increases, opening of financial recovery procedures by the the municipalities themselves, and granting interest-free loans from the state budget with strict regulations for repaying them.

\section{References}

European Charter for Local Self-Government, Prom. State Gazette, issue No 28, 1995

Local Self-Government and Local Administration Act, State Gazette, issue No.77 of 17.09.1991.

Public Finance Act, Prom., State Gazette, issue No.15 of 15.02.2013, in force since 1.01.2014.

Constitution of the Republic of Bulgaria and Program for its realization

Angelova, St., Eneva, M., Markov, A., and Savov, E., Guide for the Management of the Municipal Budget Process, LGI, S., 2006

Alexiev, Ya., Local Tax Policy as a Provocateur of Change, IME, S, 2015

Brown, S. and Jackson, P., Public Sector Economics. Adapted version under the general editing of G. Manliev, S. PSSA, 1998

Velikova, M. Financial decentralization in the spheres of manifestation of local self-government. Announcements of the Union of Scientists - Varna, Series "Humanities" 2/2005, 1 / 2006r.

Inel, B. Model of Debt Financing Capacity for Bulgarian Municipalities, S., 2005. Naydenov, L., Macroeconomic Effects of Fiscal Decentralization, S. Tax Practice magazine, Issue No. 6, 2010 
Popova T. and Nenkova, P., Fiscal Decentralization. S., 2010

Council for decentralization of government, Strategy for Decentralization, GD, 2011

Clark, T. N. \& L. Fergusson. City Money, Columbia University Press, New York, 1983

Damodaran, D. Estimating risk free rates. Working paper on http: //stern. nyu,edu/-adamodar/

Ott, K.A. Citizen's Guide to the Budget. Zagreb, 2009

Finance in Europe: Balancing the Budget and Controlling Debt, Studies in Fiscal Federalism and State-Local Finance Series, Edward Elgar, Cheltenham-Northampton, 2002

Web sites:

http://www.nispa.sk/

http://www.nambr.org/

http://stars.coe.fr

http://www.frlg.bg 


\title{
Др Иван Соколов,
}

Ванредни професор,

Висока европска школа за економију и менацмент, Софија

\section{ФИНАНСИЈСКА И ИНВЕСТИЦИОНА ПОЛИТИКА ЛОКАЛНИХ САМОУПРАВА}

\begin{abstract}
Резиме
Развој локалних политика може се дефинисати као комплексни план који обухвата заједничке циљеве и прихватљиве поступке за њихово спровођење од стране надлежног органа локалних власти. Реализација ових политика се не сме разматрати одвојено од финансијских средстава којима располаже локална самоуправа. Ако јачање демократије значи јачање локалне самоуправе, у финансијском смислу то означава постојање система финансирања месних органа власти који ће бити и ефикасан и правичан.

У овом истраживању постављамо проблеме и задатке тематског домета, који се фокусира на два главна смера у политикама локалних самоуправа, а то су: локална финансијска политика и локална инвестициона политика. Приказане су основне теоријске и методолошке концепције у области финансијске децентрализације, филозофије и логике нових метода и техника управљања, као што и многоликост предлаганих практичних решења у складу са специфичним социјалним, економским, развојним и руководним политикама, односима између различитих власти и осталим карактеристичним параметрима у развоју појединих општина.
\end{abstract}

Кључне речи: локална самоуправа, општинска инвестициона политика, јавна и приватна имовина, инвестициони ризик. 